Received:30-08-2020

Revised: 29-09-2020

Published:31-10-2020

\title{
BERPIKIR KREATIF SISWA DALAM MEMECAHKAN MASALAH OPEN ENDED DITINJAU DARI GAYA BELAJAR VISUAL
}

\author{
Ana Alfiana ${ }^{1}$, Enny Listiawati ${ }^{2}$, Ria Faulina ${ }^{3}$ \\ ${ }^{1,2,3}$ Pendidikan Matematika, STKIP PGRI Bangkalan, Indonesia \\ 1 anaalfiana1704@gmail.com \\ 2 ennylistiawati@stkippgri-bkl.ac.id \\ ${ }^{3}$ riafaulina@stkippgri-bkl.ac.id
}

\begin{abstract}
Abstrak: Penelitian ini bertujuan untuk mendeskripsikan berpikir kreatif siswa SMP dalam memecahkan masalah matematika open endedditinjau dari gaya belajar visual. Penelitian ini merupakan penelitian deskriptif kualitatif, dengan subjek penelitiannya adalah satu siswa SMP kelas VIII perempuan yang memiliki gaya belajar visual. Instrumen penelitian ini adalah soal tes gaya belajar, soal tes pemecahan masalah dan pedoman wawancara. Teknik pengambilan data dengan teknik tes dan wawancara. Analisis data dengan menggunakan tahapan reduksi data, penyajian data dan penarikan kesimpulan. Hasil penelitian menunjukkan bahwa subjek memenuhi indikator berpikir kreatif fluencypada tahap memahami masalah yaitu menyebutkan yang diketahui dan yang ditanyakan, menceritakan ulang soal dengan kalimatnya sendiri. Pada tahap merencanakan penyelesaian subjek memenuhi indikator fluency yaitu menjelaskan cara yang digunakan untuk menyelesaiakan masalah. Pada tahap melaksanakan rencana, subjek juga memenuhi indikator berpikir kreatif fluency yaitu menjelaskan dengan rinci langkah-langkah dalam menyelesaiakan masalah. Pada tahap memeriksa kembali subjek juga memenuhi indikator beripikir kreatif fluency yaitu memeriksa kesesuian hasil yang diperoleh dengan yang ditanyakan pada soal. Temuan penelitian menujukkan bahwa subjek belum memenuhi indikator berpikir kreatif flexibility dan novelty.
\end{abstract}

Katakunci:Berpikir Kreatif; Open Ended; Gaya BelajarVisual

\begin{abstract}
This study aims to describe the creative thinking of junior high school students in solving open-ended mathematics problems in terms of visual learning styles. This research is a qualitative descriptive study, with the research subject being a female junior high school student who has a visual learning style. The research instruments were learning style test questions, problem-solving test questions, and interview guides. The data collection technique used tests and interviews. Data analysis using the stages of data reduction, data presentation, and conclusion. The results showed that the subject met the fluency creative thinking indicators at the stage of understanding the problem, namely mentioning what was known and what was asked, retelling the questions in their own sentences. At the stage of planning for completion, the subject meets the fluency indicator, namely explaining the method used to solve the problem. At the stage of implementing the plan, the subject also fulfills the fluency creative thinking indicator, namely explaining in detail the steps to solve the problem. At the stage of re-checking the subject also fulfills the indicators of creative thinking fluency, which is checking the suitability of the results obtained with those asked in the questions. The research findings show that the subject has not met the indicators of creative thinking flexibility and novelty.
\end{abstract}

Keywords:Creative Thinking; Open-Ended; Visual Learning Styles

\section{Pendahuluan}

Perkembangan ilmu pengetahuan pada saat ini menuntut siswa untuk mampu bersaing mengembangkan keterampilan berpikir tingkat tinggi (Kotzer \& Elran, 2012). Yang dimaksud keterampilan berpikir tingkat tinggi adalah kemampuan untuk menggunakan 
informasi baru atau pengetahuan sebelumnya dan memanipulasinya untuk mencapai kemungkinan jawaban baru (Heong et al., 2011). Salah satu keterampilan berpikir tingkat tinggi adalah berpikir kreatif. Berpikir kreatif sangat penting dalam pendidikan karena menambah nilai pengetahuan manusia, dan dibutuhkan dalam pemecahan masalah dengan menggunakan aspek kecerdasan tertentu, seperti linguistik, matematis dan interpersonal (Trisnayanti, Ashadi, Sunarno, \& Masykuri, 2020). Selain itu, berpikir kreatif merupakan aspek penting bagi siswa untuk memecahkan masalah dan menemukan ide untuk memecahkan masalahserta melatih siswa untuk mengembangkan ide dan argumen, mengajukan pertanyaan, mengakui kebenaran argumen, bahkan membuat siswa mampu terbuka dan responsif terhadap perspektif yang berbeda.

Matematika adalah salah satu ilmu pengetahuan yang dapat melatih siswa untuk berpikir kreatif. Berpikir kreatif dalam matematika merupakan aktivitas mental manusia dalam menyelesaikan masalah matematika dengan kemampuan menemukan banyak kemungkinan jawaban atau menemukan persamaan jawaban tetapi dengan berbagai cara (Hendriyati \& Trapsilasiwi, 2017.). Akan tetapi kreativitas merupakan salah satu keterampilan berpikir yang masih kurang diperhatikan dalam pembelajaran matematika. Guru tidak menggali kreativitas siswa dalam memecahkan masalah karena soal yang diberikan hanya memiliki satu jawaban yang benar. Guru juga tidak terbiasa mengajar soal matematika yang memiliki lebih dari satu jawaban yang benar (Yanti, Koestoro, \& Sutiarso, 2018). Akibatnya siswa kurang tertarik dalam menyelesaikan masalah matematika yang menuntut kreativitas (Sari, Ikhsan, \& Saminan, 2017).
Selain itu, dalam pemecahan masalah matematika, siswa banyak mengalami kesulitan terutama dalam memecahkan soal matematika yang lebih membutuhkan penalaran. Siswa masih belum terbiasa dengan soal-soal pemecahan masalah dan umumnya mereka kurang mampu dalam menuliskan penyelesaiannya (Delyana, 2015). Pembelajaran yang dilakukan oleh guru masih konvensional dan siswa tidak mampu menerima semua materi yang dijelaskan oleh guru. Siswa hanya mengetahui materi yang diberikan oleh guru dan berpedoman dengan apa yang telah dijelaskan guru (Wanelly \& Fauzan, 2020).

Hal tersebut disebabkan karena soalsoal yang diberikan oleh guru di sekolah cenderung bersifat konvergen, yaitu jawaban dan strategi penyelesaian tunggal, sehingga guru harus melatih siswa untuk berpikir kreatif, dan siswa terbiasa untuk memecahkan masalah dengan pemikiran yang mengkombinasikan berpikir logis dan berpikir divergen. Berpikir logis adalah suatu proses berpikir dengan menggunakan logika, rasional dan masuk akal, sedangkan berpikir divergen adalah suatu pemikiran yang berorientasi pada penemuan jawaban atau alternatif yang banyak (Hidayati, 2019). Untuk mengatasi hal tersebut, salah satu solusinya adalah dengan menerapkan pendekatan open-ended dimana pendekatan open-ended dapat memfasilitasi siswa memahami ide-ide atau konsep yang tersusun secara hirarki yang terkandung dalam matematika.

Pendekatan open-ended merupakan pendekatan yang dilakukan dengan menyajikan masalah yang memiliki jawaban tidak tunggal atau cara penyelesaiannya tidak tunggal (Taufik, 2015). Pemberian soal open-ended ini dapat melatih siswa untuk berpikir kreatif. Ini dikarenakan pendekatan open- 
ended memberikan kesempatan kepada siswa untuk memperoleh pengetahuan maupun pengalaman untuk menemukan, mengenali dan memecahkan masalah tertutup ataupun terbuka dengan banyak cara sesuai dengan kemampuan yang telah dimiliki (Rahmawati ES \& Harta, 2014).

Dalam menyelesaikan soal openended diduga gaya belajar turut mempengaruhi jawaban siswa. Gaya belajar siswa merupakan salah satu unsur yang penting yang harus diperhatikan dalam proses belajar untuk mewujudkan tujuan pembelajaran matematika yang diharapkan (Umrana, Cahyono, \& Sudia, 2019). Kecenderungan gaya belajar yang dimiliki siswa memberikan pengaruh yang berbeda pada prestasi belajarnya (Ramlah, Firmansyah, \& Zubair, 2014). Adapun yang dimaksud gaya belajar adalah cara seseorang menyerap, mengatur dan mengolah informasi atau bahan pelajaran yang telah diterima selama pembelajaran (Widyawati, 2016). Gaya belajar mengacu pada cara belajar yang lebih disukai pembelajar umumnya dan berasal dari kepribadian, termasuk kemampuan kognitif dan psikologis latar belakang kehidupan, serta pengalaman pendidikan.

Keanekaragaman gaya belajar siswa perlu diketahui dari awal karena akan memudahkan bagi siswa untuk belajar maupun bagi seorang pengajar dalam proses pembelajaran. Siswa akan dapat belajar dengan baik dan hasil belajarnya baik, apabila ia mengerti gaya belajarnya sehingga hal itu memudahkan siswa dalam menerapkan pembelajaran dengan cepat dan tepat (Umrana et al., 2019). Gaya belajar merupakan cara termudah yang dimiliki oleh individu dalam menyerap, mengatur dan mengolah informasi yang diterima. Gaya belajar inilah yang bisa menyesuaikan dengan karakter atau kemampuan diri siswa.
Berdasarkan uraian di atas maka rumusan masalah dalam penelitian ini adalah bagaimana berpikir kreatif siswa kelas VIII dalam memecahkan masalah open-ended ditinjau dari gaya belajar visual? Adapun tujuan dari penelitian ini adalah untuk mendeskripsikan berpikir kreatif siswa kelas VIII dalam memecahkan masalah open-ended ditinjau dari gaya belajar visual.

\section{Metode Penelitian}

Jenis penelitian yang digunakan dalam penelitian ini adalah penelitian kualitatif yang bertujuan untuk mendeskripsikan berpikir kreatif siswa kelas VIII dalam memecahkan masalah open-ended ditinjau dari gaya belajar visual. Subjek dalam penelitian ini adalah satu siswa perempuan bergaya belajar visual yang diambil dari 32 siswa kelas VIII SMP Assomadiyah Bangkalan. Kegiatan pengambilan subjek dilakukan dengan langkah-langkah: (1) melakukan tes gaya belajar kepada 32 siswa, (2) melakukan pengelompokan subjek berdasarkan hasil tes gaya belajar yaitu kelompok siswa dengan gaya belajar visual, kelompok siswa dengan gaya belajar auditori dan kelompok siswa dengan gaya belajar kinestetik, (3) mengambil satu subjek dari kelompok siswa dengan gaya belajar visual dengan pertimbangan siswa mempunyai kemampuan matematika tinggi dan komunikatif baik lisan maupun tulisan berdasarkan saran dan masukan dari guru pengajar. Instrumen yang digunakan dalam penelitian ini adalah soal tes gaya belajar, soal tes pemecahan masalah open-ended berupa soal essay pada materi sistem persamaan linier dua variabel dan pedoman wawancara.

Pedoman wawancara dibuat oleh peneliti sebagai alat bantu untuk mengambil data di lapangan. Pedoman wawancara ini bersifat semi terstruktur yang bertujuan agar subjek 
mengemukakan pendapatnya berdasarkan hasil pekerjaan yang sudah diselesaikan. Sebelum digunakan dalam penelitian, instrumen yang telah dibuat selanjutnya divalidasi oleh dua validator. Metode pengumpulan data pada penelitian ini adalah metode angket gaya belajar, tes pemecahan masalah dan metode wawancara. Dalam penelitian ini data yang diperoleh berupa catatan hasil pekerjaan siswa dalam menyelesaikan masalah secara tertulis dan hasil wawancara siswa setelah mengerjakan soal tes. Uji kredibilitas data dengan menggunakan triangulasi sumber, yaitu pengambilan data dengan membandingkaan data hasil pekerjaan siswa dengan hasil wawancara dan dilakukan sebanyak dua kali di waktu yang berbeda yaitu pada Tes Pemecahan Masalah 1 dan Tes Pemecahan Masalah 2.

Data valid yang diperoleh kemudian dianalisis dengan menggunakan model Miles \& Huberman (Listiawati et al., 2018) yang terdiri dari tiga alur kegiatan yaitu: (1) tahap reduksi yaitu data yang telah diperoleh dari tes pemecahan masalah open-ended dan wawancara kemudian direduksi, Kegiatan mereduksi data yaitu merangkum, memilih hal-hal yang pokok, memfokuskan pada hal-hal yang penting, sehingga data yang diperoleh memberikan gambaran yang jelas tentang berpikir kreatif siswa dalam memecahkan masalah open-ended; (2) tahap penyajian data, dalam tahap ini, data diorganisasikan, tersusun dalam pola hubungan sehingga mudah dipahami. Penyajian data dilakukan dalam bentuk uraian singkat dalam bentuk tabel dan terdapat hubungan antar kategori berdasarkan indikator berpikir kreatif; (3) penarikan kesimpulan, berdasarkan paparan pada tahapan penyajian data, selanjutnya dilakukan penarikan kesimpulan yaitu dengan mendeskripsikan berpikir kreatif siswa dalam memecahkan masalah open-ended.

Dalam penelitian ini menggunakan indikator berpikir kreatif menurut Silver dan tahapan pemecahan masalah menurut Polya yang disajikan pada tabel 1 berikut ini:

Tabel 1. Indikator Berpikir Kreatif

\begin{tabular}{|c|c|c|}
\hline $\begin{array}{c}\text { Tahapan } \\
\text { Pemecahan } \\
\text { Masalah }\end{array}$ & $\begin{array}{l}\text { Berpikir } \\
\text { Kreatif }\end{array}$ & Indikator \\
\hline $\begin{array}{l}\text { Memahami } \\
\text { masalah }\end{array}$ & Fluency & $\begin{array}{l}\text { Menyebutkan apa yang } \\
\text { diketahui } \\
\text { Menyebutkan apa yang } \\
\text { ditanya } \\
\text { Menyatakan ulang } \\
\text { maksud dari soal }\end{array}$ \\
\hline $\begin{array}{l}\text { Membuat } \\
\text { rencana }\end{array}$ & Flexibility & $\begin{array}{l}\text { Menyebutkan beberapa } \\
\text { cara untuk } \\
\text { menyelesaikan } \\
\text { Menyebutkan } \\
\text { kemungkinan beberapa } \\
\text { jawaban dari soal. } \\
\text { Menyebutkan cara } \\
\text { baru untuk } \\
\text { menyelesaikan }\end{array}$ \\
\hline $\begin{array}{l}\text { Melaksanakan } \\
\text { rencana }\end{array}$ & Fluency & $\begin{array}{l}\text { Menyelesaikan } \\
\text { masalah dengan } \\
\text { menggunakan } \\
\text { beberapa cara } \\
\text { Menjelaskan setiap } \\
\text { langkah penyelesaian }\end{array}$ \\
\hline & Novelty & $\begin{array}{l}\text { Menemuka cara baru } \\
\text { dalam menyelesaikan } \\
\text { masalah. }\end{array}$ \\
\hline $\begin{array}{l}\text { Melihat } \\
\text { kembali }\end{array}$ & Fluency & $\begin{array}{l}\text { Memeriksa kembali } \\
\text { setiap langkah } \\
\text { penyelesaian } \\
\text { Dapat memeriksa } \\
\text { kembali kesesuaian } \\
\text { apa yang ditanyakan } \\
\text { dengan yang dijawab }\end{array}$ \\
\hline
\end{tabular}

\section{Hasil dan Pembahasan}

Data hasil penelitian ini berupa data hasil pengerjaan Tes Pemecahan Masalah (TPM) dan data hasil wawancara. Data hasil wawancara dari subjek dengan gaya belajar visual ditranskripsi dan dipaparkan untuk mengetahui berpikir kreatif siswa dalam memecahkan masalah open-ended pada materi sistem persamaan linier dua variabel. 
Berikutini disajikan data hasil tes tertulis dan wawancara subjek dari hasilpenelitian pada TPM 1 dan TPM 2 berdasarkan tahapan pemecahan masalah menurut Polya.
1. Tahap Memahami Masalah

Hasil pekerjaan subjek pada tahap memahami masalah pada TPM 1 dan TPM 2 dapat dilihat pada gambar 1 dan gambar 2 berikut ini:
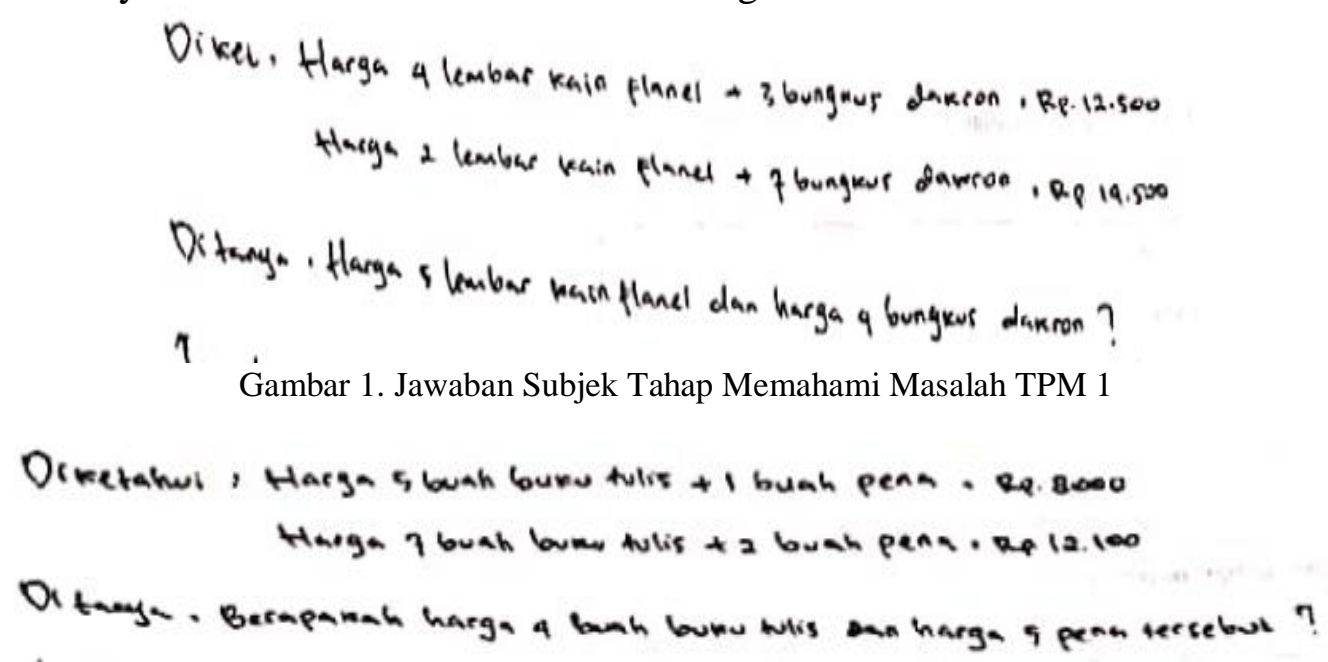

Gambar 2. Jawaban Subjek Tahap Memahami Masalah TPM 2

Berdasarkangambar 1 dan gambar 2 tersebut terlihat bahwa jawaban subjek konsisten. Subjek dapat menyebutkan yang diketahui dan yang ditanyakan pada soal. Berdasarkan hasil wawancara diperoleh subjek juga dapat menyatakan kembali maksud dari soal. Dengan demikian pada tahap memahami masalah subjek memenuhi indikator berpikir kreatif dalam memecahkan masalah open ended, yaitu pada indikator Fluency.

2. Tahap Membuat Rencana

Pada tahap membuat rencana pada TPM 1 dan TPM 2 subjek konsisten membuat pemisalan dengan menggunakan variabel $x$ dan $y$. Kemudian subjek menyusun sistem persamaan linier dalam $x$ dan $y$ sesuai dengan informasi yang diperoleh dari soal. Selanjutnya subjek merencanakan cara menyelesaiakan soal tersebut dengan terlebih dahulu mengeliminasi variabel $x$ kemudian dilanjutkan dengan substitusi untuk mendapatkan variabel $y$. Berikut ini cuplikan wawancara peneliti dengan subjek pada TPM 1 dan TPM 2 yang disajikan pada tabel 2 .
Tabel2. Cuplikan Wawancara Tahap Merencanakan pada TPM1 dan TPM 2

\begin{tabular}{lc}
\hline \multicolumn{1}{c}{ TPM 1 } & \multicolumn{1}{c}{ TPM 2 } \\
P : Langkah awal apa & P : Langkah awal apa \\
lakukan untuk & yang kamu lakukan \\
menyelesaikan & untuk \\
soal tersebut ? & tersebut ? \\
$\mathbf{S}:$ Membuat & $\mathbf{S}$ : Membuat pemisalan \\
pemisalan & terlebih dahulu bu, \\
terlebih dahulu & dimisalkan buku \\
bu, dimisalkan & tulis itu x dan pena \\
kain flanel itu x & itu y setelah itu \\
dan dakron itu y, & dijadikan model \\
setelah itu & matematikanya bu. \\
dijadikan model & $\mathbf{P}:$ Coba jelaskan \\
matematikanya. & kenapa kamu \\
$\mathbf{P}:$ Coba jelaskan & menggunakan \\
kenapa kamu & langkah awal \\
menggunakan & seperti itu ? \\
langkah awal & $\mathbf{S}:$ Karena kalau soal \\
seperti itu ! & seperti itu harus \\
$\mathbf{S}:$ Karena kalau soal & dimisalkan dahulu \\
seperti itu harus & bu, supaya kita \\
di misalkan & mudah untuk \\
terlerlebih dahulu & mengerjakannya \\
supaya kita & bu. \\
mudah untuk & $\mathbf{P}:$ Apa langkah \\
mengerjakannya & selanjutnya yang \\
bu. & akan kamu lakukan \\
$\mathbf{P}:$ Apa langkah & untuk \\
selanjutnya yang & menyelesaikan soal \\
akan kamu & tersebut ? \\
\hline
\end{tabular}


lakukan untuk menyelesaikan soal tersebut!

S : Mengeliminasi, setelah itu subsitusikan dan bisa menentukan hasilnya bu

Berdasarkan cuplikan wawancara tersebut, subjek hanya merencanakan satu cara saja untuk menyelesaiakan masalah yaitu menggunakan eliminasi yang dilanjutkan dengan substitusi. Dengan demikian subjek memenuhi indikator berpikir kreatif fluencyakan tetapi tidak memenuhi indikator berpikir kreatif flexibility dan novelty.

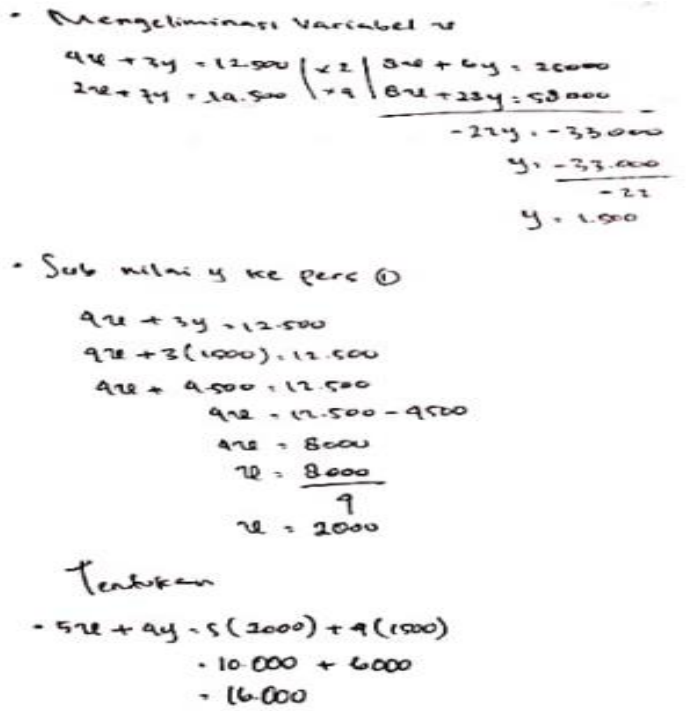

Gambar 3. Jawaban Subjek Tahap Melaksanakan Rencana pada TPM 1

Berdasarkan hasil pekerjaan subjek dan hasil wawancara diperoleh data bahwa subjek hanya menggunakan satu cara untuk mencari solusi dari permasalahan, akan tetapi subjek dapat menjelaskan dengan rinci setiap langkah untuk menyelesaikan masalah. Dengan demikian pada tahap melaksanakan rencana, subjek memenuhi salah satu indikator berpikir kreatif fluency. Akan tetapi subjek hanya menyelesaikan dengan menggunakan satu cara dan tidak menemukan cara baru untuk menyelesaiakan. Dengan demikian pada tahap melaksanakan rencana, subjek tidak
3. Tahap Menyelesaikan Rencana

Hasil pekerjaan subjek pada tahap menyelesaikan rencana pada TPM 1 dan TPM 2 dapat dilihat pada gambar 3 dan gambar 4 berikut ini:

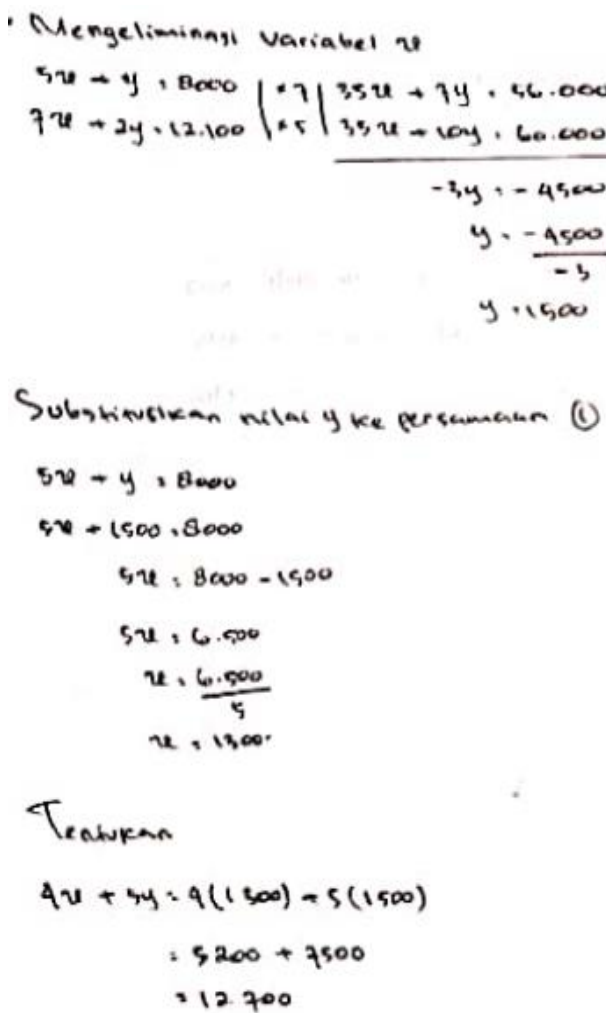

Gambar 4. Jawaban Subjek Tahap Melaksanakan Rencana pada TPM 2

memenuhi indikator berpikir kreatif flexibility dan novelty.

4. Tahap Memeriksa Kembali

Pada tahap memeriksa kembali subjek memeriksa kembali setiap langkah Penyelesaian masalah yang sudah diselesaikan. Subjek juga memeriksa kesesuaian jawaban yang diperoleh dengan yang ditanyakan pada soal. Akan tetapi subjek tidak menemukan cara baru untuk menyelesaikan permasalahan tersebut. Dengan demikian, pada tahapan memeriksa kembali subjek memenuhi indikator berpikir kreatif fluency.

Dari hasil penelitian yang telah diuraikan di atas, terlihat bahwa indikator beripikir kreatif belum sepenuhnya dikuasi oleh subjek, terutama pada 
indikator flexibilty dan novelty. Hal ini disebabkan karena siswa masih mengalami kesulitan dalam berpikir kreatif dan kritis (Kharis, Agoestanto, \& Zuhair, 2018). Dari semua tahapan pemecahan masalah, hanya indikator berpikir kreatif fluency yang memenuhi. Pada indikator flexibility diharapkan subjek dapat memberikan lebih dari satu cara penyelesaian, akan tetapi subjek tidak memenuhi itu. Sedangkan pada indikator novelty, subjek tidak dapat memenuhi itu untuk semua tahapan pemecahan masalah. Hal ini menunjukkan bahwa aspek kemampuan berpikir kreatif yang masih rendah adalah flexibility dan novelty (Wahyudi, Waluya, Rochmad, \& Suyitno, 2019).

\section{Kesimpulan}

Dari hasil penelitian dan pembahasan dapat disimpulkan bahwa siswa dengan gaya belajar visual dapat memenuhi indikator berpikir kreatif fluency dengan baik dalam memecahkan masalah openended. Subjek dapat menyelesaiakan masalah open-ended pada materi sistem persamaan linier dengan benar. Akan tetapi pada indikator flexibilty subjek belum memenuhi karena subjek hanya dapat menggunakan satu cara untuk menyelesaikan masalah. Sedangkan pada indikator berpikir kreatif novelty, subjek juga belum memenuhi karena tidak mampu menemukan cara baru untuk menyelesaikan masalah.

Dengan melihat profil berpikir kreatif siswa, diharapkan pada penelitian lanjutan dapat dianalisis metode yang tepat untuk meningkatkan kemampaun berpikir kreatif siswa. Dari temuan oenelitian ini diharapkan kedepannya dapat dikembangkan berbagai model pembelajaran oleh guru yang dapat melatih siswa untuk berpikir kreatif.

\section{Ucapan Terima Kasih}

Peneliti menyampaikan ucapan terimakasih kepada SMP Assomadiyah Bangkalan yang telah berkenan menjadi tempat penelitian, serta kepada Program Studi Pendidikan Matematika STKIP PGRI Bangkalan yang telah memberikan fasilitas sehingga penelitian ini terlaksana dengan baik.

\section{Referensi}

Delyana, H. (2015). Peningkatan Kemampuan Pemecahan Masalah Matematika Siswa Kelas VII Melalui Penerapan Pendekatan Open Ended. Lemma, 2(1), 26-34.

Hendriyati, N. N., Trapsilasiwi, D., \& Susanto, S. (2017). Profil Berpikir Kreatif Siswa Kelas VII B SMP Negeri 6 Jember dalam Memecahkan Masalah Operasi Pecahan Berdasarkan Tahapan Wallas Ditinjau dari Perbedaan Gender. KadikmA, 8(2), 189-196..

Heong, Y. M., Othman, W. B., Yunos, J. B. M., Kiong, T. T., Hassan, R. Bin, \& Mohamad, M. M. B. (2011). The Level of Marzano Higher Order Thinking Skillsamong Technical Education Students. International Journal of Social Science and Humanity, 1(2), 121-125. https://doi.org/10.7763/ijssh.2011.v1 .20

Hidayati, N. (2019). Pengembangan Media Pembelajaran Berbasis Video Scribe sebagai Bahan Pengamatan pada Mata Pelajaran Pengelolaan Kas Kelas $\mathrm{Xi}$ Perbankan Smk Negeri 1 Jombang. Jurnal Pendidikan Akuntansi (JPAK), 7(3).

Kharis, M., Agoestanto, A., \& Zuhair, M. (2018). Misconception as a critical and creative thinking inhibitor for mathematics education students. Unnes Journal of Mathematics Education, 7(1), 57-62. https://doi.org/10.15294/ujme.v7i1.1 
8078

Kotzer, S., \& Elran, Y. (2012). Learning and teaching with Moodle-based E-learning environments, combining learning skills and content in the fields of Math and Science \& Technology.

Listiawati, E. (2019). Profil Pemahaman Siswa SD yang Berkemampuan Tinggi pada Masalah Kalimat Matematika. Prosiding

Silogisme, 1(1).

Rahmawati ES, Y., \& Harta, I. (2014). Keefektifan Pendekatan OpenEnded dan CTL Ditinjau dari Hasil Belajar Kognitif dan Afektif. Jurnal Riset Pendidikan Matematika, 1(1), 113.

https://doi.org/10.21831/jrpm.v1i1.2 669

Ramlah, Firmansyah, D., \& Zubair, H. (2014). Pengaruh Gaya Belajar dan Keaktifan Siswa Terhadap Prestasi Belajar Matematika ( Survey Pada SMP Negeri di Kecamatan Klari Kabupaten Karawang). Jurnal Ilmiah Solusi, 1(3), 68-75.

Sari, A. P., Ikhsan, M., \& Saminan, S. (2017). Proses Berpikir Kreatif Siswa dalam Memecahkan Masalah Matematika Berdasarkan Model Wallas. Beta Jurnal Tadris Matematika, $\quad 10(1), \quad 18$. https://doi.org/10.20414/betajtm.v10 i1. 102

Taufik, A. (2015). Penerapan Pendekatan Pembelajaran Open Ended Dan Problem Posing Dengan Media Pohon Matematika Untuk Meningkatkan Kemampuan Berpikir Kreatif Dan Hasil Belajar. JPM: Jurnal Pendidikan Matematika, 1(2), 154. https://doi.org/10.33474/jpm.v1i2.72 3

Trisnayanti, Y., Ashadi, Sunarno, W., \& Masykuri, M. (2020). Creative thinking profile of junior high school students on learning science. Journal of Physics: Conference
Series,

1511(1). https://doi.org/10.1088/17426596/1511/1/012072

Umrana, Cahyono, E., \& Sudia, M. (2019). Analisis Kemampuan Pemecahan Masalah Matematis Ditinjau dari Gaya Belajar Siswa. Jurnal Pembelajaran Berpikir Matematika, 4(1), 67-76.

Wahyudi, W., Waluya, S. B., Rochmad, R., \& Suyitno, H. (2019). Mathematical Creative Thinking Ability and Scaffolding Process According with Learning Styles for Pre-Service Teachers. Anatolian Journal of Education, 3(1), 39-50. https://doi.org/10.29333/aje.2018.31 $4 \mathrm{a}$

Wanelly, W., \& Fauzan, A. (2020). Pengaruh Pendekatan Open Ended dan Gaya Belajar Siswa terhadap Kemampuan Berpikir Kreatif Matematis. Jurnal Basicedu, 4(3), 523-533.

https://doi.org/10.31004/basicedu.v4 i3.388

widyawati, S. (2016). Pengaruh Gaya Belajar Terhadap Prestasi Belajar Mahasiswa Program Studi Pendidikan Matematika (IAIM NU) Metro Santi. Jurnal Pendidikan Matematika, 7(1), 107-114. Retrieved from fredigpsw@gmail.com

Yanti, A. P., Koestoro, B., \& Sutiarso, S. (2018). The Students' Creative Thinking Process based on Wallas Theory in Solving Mathematical Problems viewed from Adversity Quotient /Type Climbers. Al-Jabar : Jurnal Pendidikan Matematika, 9(1), 51. https://doi.org/10.24042/ajpm.v9i1.2 331 